Pérez-Postigo, I., Vibrans, H., Bendix, J., \& Cuevas-Guzmán, R. (2021). Floristic composition and potential invasiveness of alien herbaceous plants in Western Mexico. Revista de Biología Tropical, 69(3), 1037-1054. https://doi. org/10.15517/rbt.v69i3.45855

\title{
Floristic composition and potential invasiveness of alien herbaceous plants in Western Mexico
}

Isabel Pérez-Postigo ${ }^{1 *}$; (D) https://orcid.org/0000-0002-9974-9198

Heike Vibrans ${ }^{2}$; (D) https://orcid.org/0000-0002-1800-4320

Jörg Bendix ${ }^{3}$; (D) https://orcid.org/0000-0001-6559-2033

Ramón Cuevas-Guzmán; (D) https://orcid.org/0000-0002-4980-8989

1. Programa de Doctorado en Biosistemática, Ecología, Manejo de Recursos Naturales y Agrícolas, Universidad de Guadalajara, Autlán de Navarro, Jalisco, Mexico; perezpostigo@gmail.com (*Correspondence)

2. Posgrado en Botánica, Colegio de Postgraduados, Texcoco, Estado de Mexico, Mexico; heike@colpos.mx

3. Faculty of Geography, Philipps Universität Marburg, Marburg, Hessen, Germany; bendix@mailer.uni-marburg.de

4. Departamento de Ecología y Recursos Naturales, Universidad de Guadalajara, Autlán de Navarro, Jalisco, Mexico; rcuevas@cucsur.udg.mx

Received 16-II-2021. Corrected 30-VII-2021. Accepted 07-IX-2021.

\begin{abstract}
Introduction: Numbers of alien plant species are rising around the globe, but not all of them become invasive. Whereas introductions have been documented for several decades in some regions of the world, knowledge on alien species in Western Mexico is limited. Here, we study roadside vegetation along an elevational gradient, which includes a protected area.

Objective: We analysed the floristic composition of herbaceous alien species, their distribution patterns, and their relationship with various environmental factors. A relative importance value index (IVI) identified the most important and, therefore, probably invasive taxa.

Methods: During 2017 and 2018, roadside vegetation was documented with 4-6 transects every 300 altitudinal meters, from 0 to $2100 \mathrm{~m}$, for a total of 37 transects. Each transect consisted of five $1 \mathrm{~m}^{2}$ plots. All herbaceous species were registered and alien taxa identified. A cluster analysis distinguished grouping of species based on elevation. The potentially invasive species were identified by their IVI, based on the sum of relative frequency and density values. The influence of environmental variables was analysed with a canonical correspondence analysis.

Results: Most alien species were grasses; other families were represented by one or two species. The species were grouped into three main clusters. The first group included rare species, the second consisted of species restricted to higher altitudes, and the third group were tropical taxa with a distribution from sea level to medium altitudes. The most important potentially invasive species were: Urochloa maxima, Melinis repens, Eragrostis ciliaris and Cynodon dactylon, all African grasses introduced for grazing. The IVI of the species was related to tree cover, leaf litter depth and surface stone cover for some species and, for others, to soil compaction, distance to major roads and elevation.

Conclusions: The alien ruderal species clustered according to the general climate (temperate vs. tropical). Grasses of African origin are of highest concern as invasive species. Although most introductions are related to human disturbance, each species becomes dominant under certain environmental conditions. Thus, management programs must be specifically adjusted to each individual invasive alien.
\end{abstract}

Key words: environmental variables; exotic plants; invasive herbs; ruderal weeds; Sierra de Manantlán. 
Ecosystems have been influenced by human activities over several millennia. However, the most apparent impact has been landuse change. Over the last 100 years, more than $50 \%$ of the habitable land surface has been converted into urban areas, crop fields and rangelands (Ellis et al., 2010). Much more inconspicuous, but also an important factor of anthropogenic influence, are introductions of alien plant and animal species to new regions (Ellis et al., 2010; Elton, 1958; Mack, 1991). This human mediated transfer of species is the largest in the evolutionary history of the planet (Elton, 1958; Mack et al., 2000), such that at least 13168 plant species worldwide are naturalised outside their original distribution (van Kleunen et al., 2015a). These species are considered a major threat to local natural ecosystems (Espinosa-García \& Villaseñor, 2017; Rejmánek et al., 2005; Villaseñor \& Espinosa-García, 2004) as some of them have been shown to change the structure and functioning of ecosystems (Elton, 1958; Pejchar \& Mooney, 2009).

Not all introduced alien species can naturalise in a new environment, and naturalised species do not necessarily become invasive and cause harm (Richardson et al., 2000). Williamson and Fitter (1996a) proposed the "rule of 10 " that states that only about $10 \%$ of all introduced species become casual, and $10 \%$ of these naturalise. Of the naturalised species, around $10 \%$ become invasive (Jarić \& Cvijanovic, 2012; Williamson \& Fitter, 1996a). There is much regional variation in the proportions (Jarić \& Cvijanovic, 2012; Jeschke et al., 2012). Although the "rule of 10" is not a precise rule and has been criticised, it can provide guidance (Jarić \& Cvijanovic, 2012). Of course, the other $90 \%$ of the naturalised species may become invasive in the future, particularly under changing circumstances, and their potential impact on natural ecosystems should therefore not be underestimated (Simberloff, 2011).

Three main drivers of invasion success exist: (i) invasibility of the site, (ii) propagule pressure and (iii) traits of the species related to their invasiveness (Barney \& Whitlow, 2008; Catford et al., 2009). The invasibility of a habitat is related to different factors. In general, disturbed or anthropogenically modified habitats are more prone to invasions than natural sites (Barney \& Whitlow, 2008; Hierro et al., 2005). To form a population large enough to survive, reproduce and naturalise, a species needs to be introduced in large numbers or be able to produce sufficient propagule pressure (van Kleunen et al., 2015b; Williamson \& Fitter, 1996b). Although scientists agree that the invasion success of the species depends on their biological traits, no general set of traits responsible for invasiveness has been determined. Traits seem to be different for each ecosystem and vary depending on the stages of the invasion process (Sol, 2007). The distribution and abundance of the species in their native range can also influence invasion success. Species with a wide environmental aptitude in their native range can be expected to adapt to a wide range of conditions in the new environment (Dawson et al., 2009).

Alien species richness is often high at low elevations and decreases with altitude (Alexander et al., 2011; Pauchard \& Alaback, 2004). Most alien species are introduced in high-density areas of human population, which is generally concentrated at low and medium elevations (Alexander et al., 2011; Pauchard, et al., 2009). A unidirectional expansion of alien species to higher elevations causes directional filtering of species with narrow climatic tolerances. Environmental conditions at high elevations may be extreme; nevertheless, alien species here are generally not highly specialised but generalists (Alexander et al., 2011). Even though fewer introduced species are present at higher elevations, those species may pose a relatively greater risk to native ecosystems (Alexander et al., 2011; Pauchard et al., 2009) because generalists can be expected to be less affected by disturbance and climate change than native and highly specialised species. However, whether this applies to Mexico with its high-altitude population centres remains to be seen. 
The present-day number of documented alien plant species in Mexico is between 700 and 750. Most of them are herbaceous weeds and grasses (Espinosa-García et al., 2004; Espinosa-García \& Villaseñor, 2017). Between 58 and 180 weed species are invasive and may be causing environmental or socioeconomic damage (Espinosa-García \& Villaseñor, 2017). A relationship of alien species richness and abundance to altitude and other environmental factors was not found (Pérez-Postigo et al., 2021; Sánchez Medrano 2018). However, knowledge of single species distribution patterns and floristic groups is still lacking.

We analyse the floristic composition of alien herbaceous species and their clustering over an elevation gradient in Western Mexico. We expect them to form floristic groups related to climate, and the species' origin (Dawson et al., 2009). Also, we study their relationship to different environmental variables. We then aim to identify the alien herbaceous species which might be invasive in the region. We indicate the origin of these invasive taxa and discuss their traits as well as their invasion success in other introduced ranges. We expect paleotropical grasses to be the most invasive taxonomic group. They are known invaders in other tropical American regions, growing at a wide range of sites that includes different environmental conditions (Pauchard et al., 2009; Williams \& Baruch, 2000).

\section{MATERIALS AND METHODS}

Study site: We worked in the Sierra de Manantlán and the surrounding areas in the states of Colima and Jalisco in Western Mexico. The Sierra runs from Northeast to Southwest and is part of the Sierra Madre del Sur. The subtropical climate has a dry and a rainy season. The precipitation patterns vary with exposure: the Southern and South-Eastern slopes are windward and humid; the Northern ones are dry with semi-desertic conditions (Vázquez García et al., 1995).

The region has a wide range of natural and human-modified vegetation types (INE,
2000; Vázquez García et al., 1995). Coastal mangroves are dominated by Conocarpus erectus L., Laguncularia racemosa (L.) C.F. Gaertn, and Rhizophora mangle L., which are sometimes displaced by plantations of Cocos nucifera L., with herbaceous plants in the understory. Tropical dry and subhumid forests are the natural vegetation of the coastal plain and elevations up to $1700 \mathrm{~m}$ where the herbaceous vegetation is dominated by geophytes (Cruz Angón et al., 2017; Vázquez García et al., 1995). Cloud forests with high numbers of epiphytes, lianas and other herbaceous species cover humid locations at elevations between 700 and $2600 \mathrm{~m}$ (Rzedowski, 1978; Rzedowski \& McVaugh, 1966). Quercus and Pinus forests are found at higher elevations, with Abies and Cupressus covering smaller patches (Rzedowski, 1978; Rzedowski \& McVaugh, 1966; Vázquez García et al., 1995). The region is known to harbour a relatively high number of endemic plants (Vázquez García et al., 1995). Humans have influenced the region since preColumbian times (Kelly, 1945).

Data: We focused on ruderal vegetation along an elevational gradient of over $2100 \mathrm{~m}$, from sea level near the village of La Manzanilla (La Huerta, Jalisco) to upper parts of the Sierra de Manantlán, during the years 2017 and 2018. Transects were located as close as possible to eight predetermined elevation levels, $300 \mathrm{~m}$ apart in altitude. Sites with ruderal vegetation, at least $5 \mathrm{~m}$ wide and $25 \mathrm{~m}$ long parallel to major or minor roads, were selected. Also, we considered personal security when selecting the sites. We surveyed between four to six transects per elevation level. Each transect with a length of $20 \mathrm{~m}$ contained $1 \mathrm{~m}^{2}$ plots every five meters (for further details of sampling methods, see Pérez-Postigo et al., 2021).

All herbaceous species within the $1 \mathrm{~m}^{2}$ plots were registered and all individuals counted. For species with stolons or rhizomes, groups of culms were counted as separate individuals. The species were identified in the field if possible; one of the authors (RCG) is a specialist of the regional flora. We collected several 
individuals from every unknown morpho-species for identification and three individuals from every known species for documentation. The vouchers were deposited at the ZEA Herbarium of the University of Guadalajara in Autlán de Navarro. We consulted specialised literature on regional flora, identification keys and the ZEA Herbarium for identification of the 500 collection numbers, resulting in 317 identified species. One specimen was a new species, not yet described, and thirty-five specimens could be determined only to the genus level. To identify the alien species, we considered the publications of Villaseñor and Espinosa-García (2004) and Espinosa-García and Villaseñor (2017). Synonymy was vetted with the Tropicos database (www.tropicos.org).

Environmental information on nutrient, water and light resources with possible explanatory value for the herbaceous diversity distribution was documented in the field (Chapin et al., 1987). Geographic position and elevation were measured with a Garmin etrex GPS, and the slope of the transect was determined in \% with a Haga clinometer. Slope affects soil drainage and depth, which influence vegetation types, dispersal, diversity, richness and growth. On steeper slopes, rainwater runoff is higher and soil erosion also increases (Neal, 1938). For each plot, the surface stone cover percentage was estimated in five categories. This is an important variable since stone cover acts as protection for the soil against erosion (Mandal et al., 2005). Leaf litter depth was measured in $\mathrm{cm}$ and the leaf litter cover estimated as a percentage. Both values were captured per plot and was expected to positively correlate with nutrient availability in the soil (Bastida et al., 2008). Compaction of topsoil as the unconfined strength of $\mathrm{kg} / \mathrm{cm}^{2}$ was measured for every plot using a pocket penetrometer from Soil Test Inc. Topsoil density is an important variable for plant water and nutrient uptake and an indicator of disturbance such as grazing or vehicle movement (Passioura, 1991; Woodward, 1996). To measure the available light from solar radiation at each plot, we estimated the percentage of tree cover with a spherical densiometer from Robert E. Lemmon Forest Densiometers. We classified the influence of grazing and fire intensity of every plot in five categories, from none to severe. Mean values per transect were calculated using all registered data on the $1 \mathrm{~m}^{2}$ plots.

The distance to paved federal and state roads and highways was calculated in QGIS (version 3.6.2, QGIS.org, 2019) as the 2D distance between transects and the nearest point on these major roads or highways; in some cases, the transects were along such roads and so the distance was 3-5 $\mathrm{m}$. The data for roads and highways were obtained from the Atlas de Caminos y Carreteras del Estado de Jalisco from the year 2012 published by the Government of the State of Jalisco (Gobierno de México, 2018). Temperature and precipitation regimes are known to be essential for plant species distribution patterns, thus we included temperature and precipitation variables (Chapin et al., 1987). Monthly temperature and precipitation data at a 30 -arc $\mathrm{s}$ resolution $\left(1 \mathrm{~km}^{2}\right)$ were downloaded from the Worldclim database, which offers mean values of the period 1950 to 2000, interpolated from data of different sources (Hijmans et al., 2005). We calculated the annual mean temperature and the annual precipitation sum, using QGIS to extract the monthly data and $\mathrm{R}$ (version 4.0.2, $\mathrm{R}$ Core Team, 2020) to calculate the annual sum and mean.

Data analysis: We used the importance value index (IVI) (Curtis \& McIntosh, 1951) as a measure of invasiveness of a species. IVI is considered a good indicator of the functional 
importance of a species in a community, as it is based on relative density and frequency values expressed as percentages per transect (Catford et al., 2012; Curtis \& McIntosh, 1950):

$$
\begin{aligned}
& \text { relative density of species } A=\frac{\text { number of individuals of species } A}{\text { total number of individuals of all species }} \times 100 \\
& \text { relative frequency of species } A=\frac{\text { frequency of species } A}{\text { sum of frequency values for all species }} \times 100 \\
& \qquad I V I=\text { relative density of species } A+\text { relative frequency of species } A
\end{aligned}
$$

A cluster analysis identified floristic groups along the elevation gradient. For this, the species were standardised by dividing their IVI in each transect by the sum of their IVI in all transects in which the species is found and multiplying the result by 100 . With the matrix of standardised values, we obtained the Bray-Curtis similarity between pairs of species, known as the Whittaker index of species association (Clarke et al., 2014). The cluster analysis was based on these values, using group averages as the joining method, accompanied by a similarity profile test (SIMPROF) type 2 and 3 . The type 2 test is based on the null hypothesis of the non-existence of associations between the species. The type 3 test examines the non-existence of differences between the groups of species with a statistical permutation test for which more information can be found in Clarke et al. (2014). A heatmap-plot ("heatmap" function stats package, R Core Team, 2020) of the IVI natural logarithm showed the IVI of all species.

To explore the relationship between species IVI and environmental variables for all transects, we used the canonical or constrained correspondence analysis (CCA) by applying the "cca" function from the vegan package in R (Oksanen et al., 2019). Direct ordination techniques such as CCA are widely used to explore relationships between environmental variables and the distribution and abundance of species (Borcard et al., 1992). We reduced the set of environmental variables using the "findCorrelation" function of the caret package (Kuhn, 2020). We identified and excluded the following four highly intercorrelated variables: mean temperature, distance to highways, fire intensity and leaf cover. To test the significance of the CCA, an ANOVA-like permutation test ("anova.cca" function) was run for the whole CCA and for each axis separately (Oksanen et al., 2019).

We considered the four most dominant and widespread species to be invasive, based on the tens rule (only about $10 \%$ of naturalised species become invasive) (Jarić \& Cvijanovic, 2012; Williamson \& Fitter, 1996b) and the IVI. A CCA was run for these four species, using the vegan package in $\mathrm{R}$ (Oksanen et al., 2019). For the CCA, five highly correlated variables were excluded: mean temperature, fire intensity, leaf cover, slope and the distance to roads.

\section{RESULTS}

Floristic composition: Of the 317 identified species, 285 were natives belonging to 175 genera and 45 families. The 32 alien species from 27 genera and 11 families represented $10.09 \%$ of all collected species, but they accounted for $16.59 \%$ of all plant individuals. Along the entire elevation gradient Asteraceae (41), Poaceae (40) and Fabaceae (38) had the most native species, followed by Malvaceae (21), Cyperaceae (15), Convolvulaceae (12), Commelinaceae (10) and Euphorbiaceae (10). The other families had fewer than 10 species, most of them only one. There were 20548 native plant individuals in the transects. Native species of Asteraceae were the most abundant with over 5500 individuals; native Poaceae and Fabaceae had around 3850 individuals. The families Convolvulaceae, Malvaceae, Lamiaceae and Caryophyllaceae had abundances of over 500 individuals each.

The family with the highest number of alien species was Poaceae with 20 species and 
16 genera. The family Asteraceae had two alien species from two genera and Primulaceae two Anagallis species. All the other 10 families were represented by only one alien species and one genus. Poaceae was the most abundant family with 3943 individuals of alien species, followed by Primulaceae with 43 plants and Asteraceae with 35 (Table 1). The 12 most abundant alien species were grasses, followed by Taraxacum officinale (Asteraceae),
Achyranthes aspera (Amaranthaceae), and other grasses. The median of native abundances was 14 individuals per species.

The average IVI, which is the sum of the average relative density and the average relative frequency of the alien species over all transects, varied from 11.46 for Urochloa maxima to 0.03 for Raphanus raphanistrum. The species with the highest total abundance (number of individuals over all transects) was

TABLE 1

Alien species registered in 37 transects in the study area (Pérez-Postigo et al., 2021) and their importance

\begin{tabular}{|c|c|c|c|c|c|c|}
\hline Family & Species & Acronym & $\begin{array}{c}\text { Average } \\
\text { IVI }\end{array}$ & $\begin{array}{l}\text { Total abundance/ } \\
\text { number of } \\
\text { individuals }\end{array}$ & $\begin{array}{c}\text { Average } \\
\text { relative } \\
\text { density in \% }\end{array}$ & $\begin{array}{c}\text { Average } \\
\text { relative } \\
\text { frequency in \% }\end{array}$ \\
\hline Amaranthaceae & Achyranthes aspera $\mathrm{L}$. & Achasp & 1.01 & 33 & 0.51 & 0.50 \\
\hline Apiaceae & Apium graveolens $\mathrm{L}$. & Apigrav & 0.13 & 6 & 0.02 & 0.11 \\
\hline Araceae & Zantedeschia aethiopica (L.) Spreng. & Zanaet & 0.07 & 10 & 0.03 & 0.04 \\
\hline Asteraceae & Sonchus oleraceus L. & Sonole & 0.03 & 1 & 0.00 & 0.03 \\
\hline Asteraceae & Taraxacum officinale L. & Taroff & 0.22 & 34 & 0.10 & 0.12 \\
\hline Brassicaceae & Raphanus raphanistrum $\mathrm{L}$. & Raprap & 0.03 & 1 & 0.00 & 0.02 \\
\hline Cannaceae & Canna indica $\mathrm{L}$. & Canind & 0.07 & 5 & 0.03 & 0.04 \\
\hline Cucurbitaceae & Momordica charantia L. & Momcha & 0.17 & 1 & 0.02 & 0.14 \\
\hline Molluginaceae & Mollugo verticillata $\mathrm{L}$. & Molver & 0.10 & 6 & 0.05 & 0.05 \\
\hline Poaceae & Andropogon gayanus Kunth & Andgay & 0.76 & 56 & 0.38 & 0.37 \\
\hline Poaceae & Bromus catharticus Vahl & Brocat & 0.05 & 2 & 0.01 & 0.04 \\
\hline Poaceae & Cenchrus ciliaris L. & Cencil & 2.24 & 1005 & 1.75 & 0.49 \\
\hline Poaceae & Chloris gayana Kunth & Chlgay & 0.11 & 18 & 0.05 & 0.07 \\
\hline Poaceae & Chloris inflata Link & Chlinf & 0.20 & 15 & 0.05 & 0.15 \\
\hline Poaceae & Cynodon dactylon (L.) Pers. & Cyndac & 2.88 & 250 & 2.14 & 0.74 \\
\hline Poaceae & Cynodon nlemfuensis Vanderyst & Cynnle & 1.98 & 190 & 1.26 & 0.72 \\
\hline Poaceae & Dactyloctenium aegyptium (L.) Willd. & Dacaeg & 0.55 & 79 & 0.28 & 0.28 \\
\hline Poaceae & Digitaria bicornis (Lam.) Roem. \& Schult. & Digbic & 0.55 & 99 & 0.19 & 0.35 \\
\hline Poaceae & Digitaria ciliaris (Retz.) Koeler & Digcil & 2.02 & 154 & 1.48 & 0.54 \\
\hline Poaceae & Echinochloa colona (L.) Link & Echcol & 0.16 & 5 & 0.02 & 0.15 \\
\hline Poaceae & Eleusine indica (L.) Gaertn. & Eleind & 0.74 & 33 & 0.14 & 0.61 \\
\hline Poaceae & Eragrostis ciliaris (L.) R. Br. & Eracil & 3.85 & 305 & 3.09 & 0.76 \\
\hline Poaceae & Melinis repens (Willd.) Zizka & Melrep & 4.94 & 1138 & 3.42 & 1.52 \\
\hline Poaceae & Pоа аппиа $\mathrm{L}$. & Poaann & 0.51 & 75 & 0.21 & 0.30 \\
\hline Poaceae & Setaria adhaerens (Forsk.) Chiov. & Setadh & 0.42 & 18 & 0.12 & 0.30 \\
\hline Poaceae & Sorghum halepense (L.) Pers. & Sorhal & 1.01 & 31 & 0.64 & 0.38 \\
\hline Poaceae & Urochloa maxima (Jacq.) R. D. Webster & Uromax & 11.46 & 235 & 6.20 & 5.26 \\
\hline Poaceae & Urochloa mutica (Forssk.) T.Q.Nguyen & Uromut & 0.11 & 4 & 0.03 & 0.08 \\
\hline Poaceae & Vulpia myuros (L.) C.C. Gmel. & Vulmyu & 0.85 & 231 & 0.60 & 0.25 \\
\hline Polygonaceae & Rumex crispus $\mathrm{L}$. & Rumcri & 0.09 & 5 & 0.01 & 0.08 \\
\hline Primulaceae & Anagallis arvensis $\mathrm{L}$. & Anaarv & 0.41 & 23 & 0.12 & 0.28 \\
\hline Primulaceae & Anagallis minima (L.) E.H.L. Krause & Anamin & 0.09 & 20 & 0.04 & 0.05 \\
\hline
\end{tabular}

IVI (importance value index) $=$ relative density of a species + relative frequency of a species. 
Melinis repens with 1138 individuals, followed by Cenchrus ciliaris with 1005 . Three species, Momordica charantia, Sonchus oleraceus and Raphanus raphanistrum, had only one individual each. The median of alien abundances was 27 individuals per species. Although total abundance was highest for $M$. repens and $C$. ciliaris, the average relative density as well as the average relative frequency were highest for Urochloa maxima.

Floristic groups: The cluster analysis showed three groups that were significantly different from each other (Fig. 1). The difference between groups two and three had a p-value of 0.003 , and the difference between both (2 and 3 together) and the first group was $\mathrm{P}=0.004$ (marked as A and B in Fig. 1). All other subgroups had higher $\mathrm{p}$-values and thus were not statistically different from each other (Fig. 1). The first group consisted of Anagallis minima with Raphanus raphanistrum, and Andropogon gayanus with Setaria adhaerens, all of which were species that appeared only once. The second group included Anagallis arvensis, Cynodon nlemfuensis, Bromus catharticus, Rumex crispus, Taraxacum officinale, Zantedeschia aethiopica, Apium graveolens, Poa annua, Sonchus oleraceus and Vulpia myurus, which were found at higher elevations (Fig. 1 and Fig. 2). All the other 18 species were grouped in the third cluster. They were tropical species widely distributed over most of the elevation gradient.

The IVI of each species in each transect over the elevation gradient is shown in Fig. 2. The data were log transformed in order to better show low IVIs. Although some transects had no alien species, all elevation levels had alien species with high (200) or medium (100) IVI.

Relationship to environmental variables: The CCA showed that some species had no relation to the documented environmental variables (Fig. 3). However, Melinis repens, Eragrostis ciliaris, Setaria adhearens and Andropogon gayanus were positively

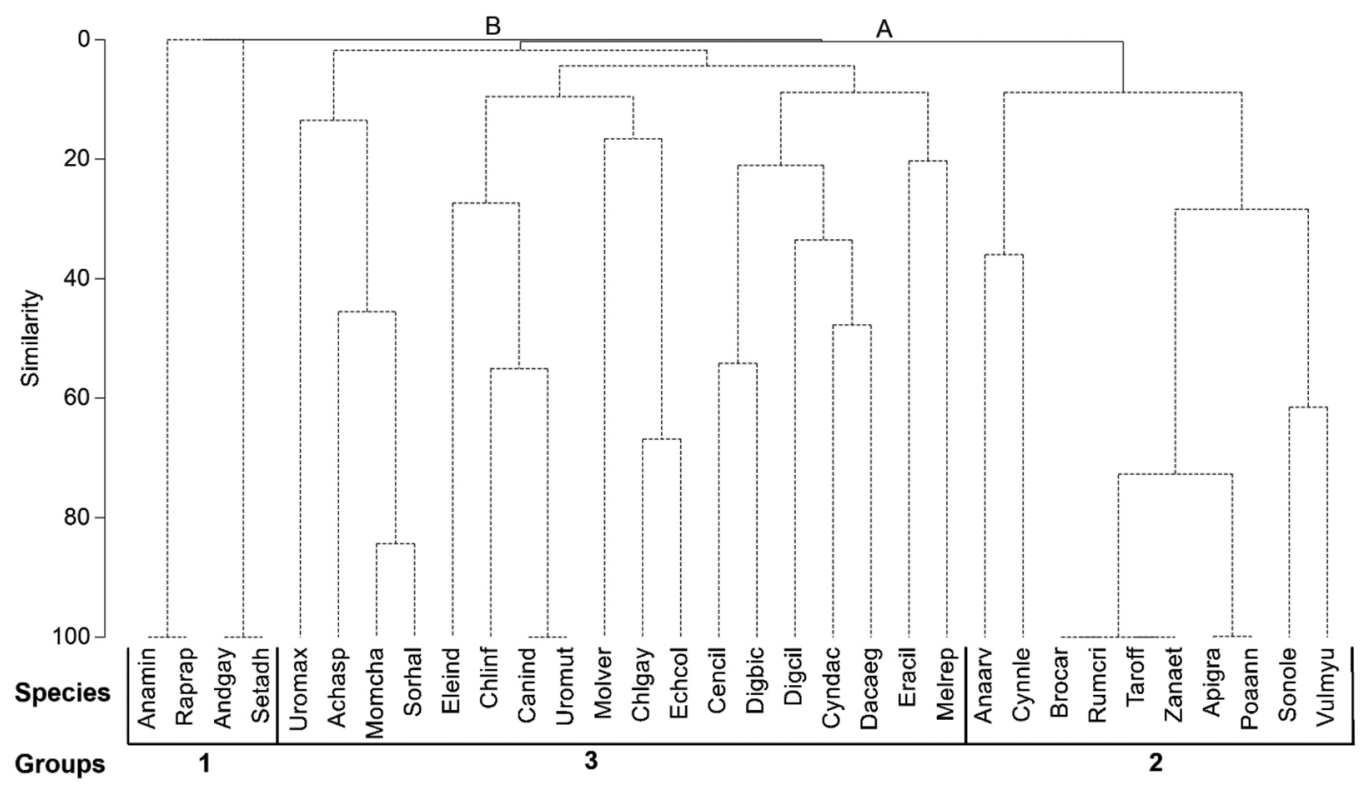

Fig. 1. Dendrogram showing the association of alien species. Solid lines delimit statistically different groups of species. Letters represent the statistical differences between groups. Differences between groups two and three are shown by A $\pi$ $=2.34, \mathrm{P}=0.003$. The difference between the group two and three combination and group one is shown by $\mathrm{B} \pi=2.1, \mathrm{P}=$ 0.004 . For the acronyms, see Table 1 . 


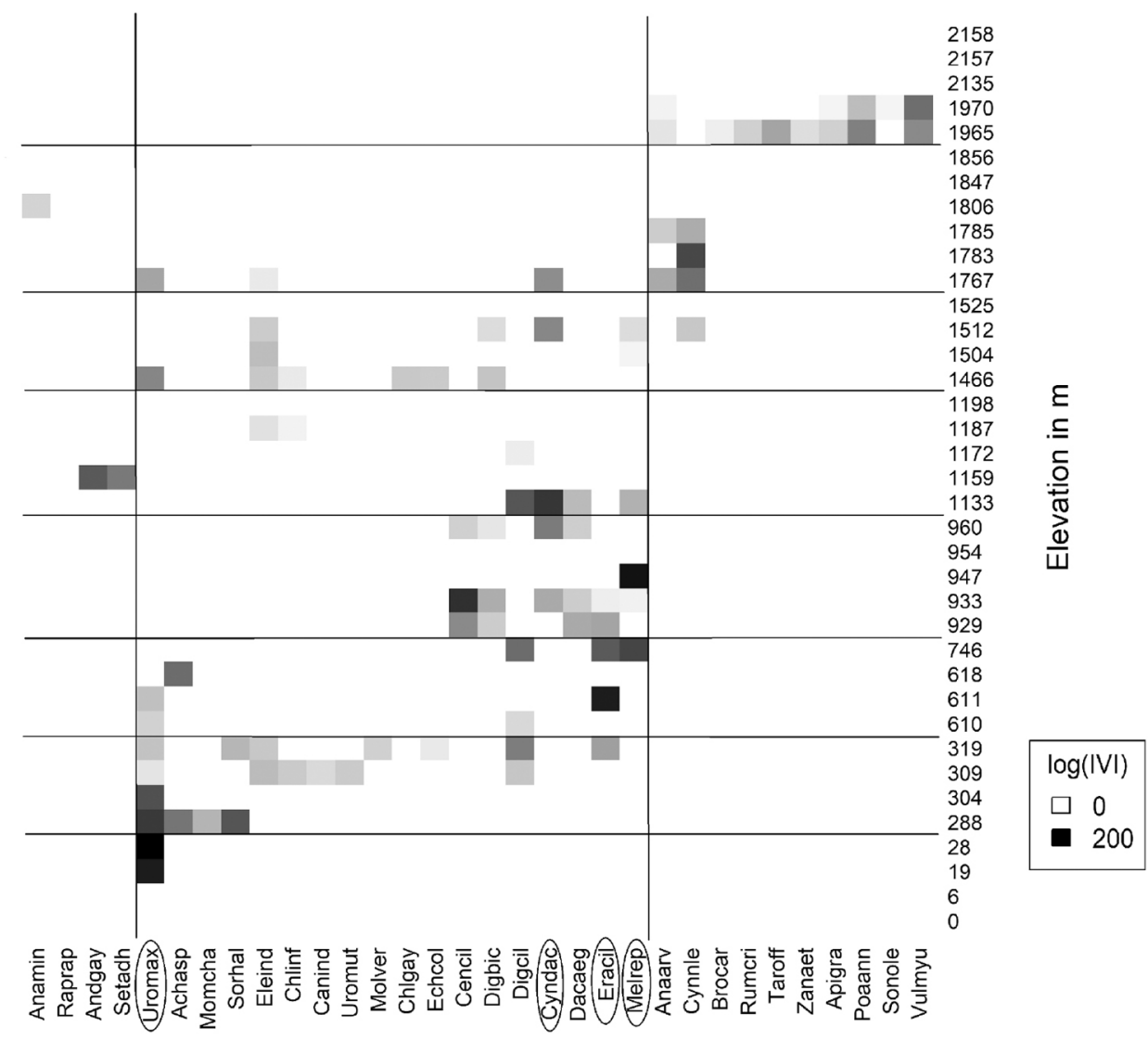

Fig. 2. Heat map, showing the log-transformed IVI of alien species over the elevation gradient. Horizontal lines divide the eight elevation groups and vertical lines divide the three groups of species determined by the cluster analysis. Darker colours show higher values; white squares indicate absence of the alien species. The four most important species with the highest IVI are circled. For the acronyms see Table 1.

associated with soil compaction, stone cover and distance to roads. Achyranthes aspera, Momordica charantia, Urochloa maxima and Sorghum halepense were related positively to leaf litter depth and tree cover. A large group of species, plotted at the lower portion of Fig. 3 , was positively related to the elevation and slope of the transects. Annual precipitation sum and grazing intensity were the variables with least impact on the IVI of the species.

Potentially invasive species: The species with the highest mean IVI were Urochloa maxima (Guinea grass), Melinis repens (Natal grass), Eragrostis ciliaris and Cynodon dactylon (Bermuda grass). Urochloa maxima not only had the highest IVI but was also the most abundant species, followed by other grasses, but in a different order: Melinis repens, Cynodon dactylon and Eragrostis ciliaris. Total abundance varied from 1 to over 1000 individuals, and no species was present in more than 31 of the 185 plots.

These four species were mainly found at medium elevations (Fig. 2). However, their abundances varied between species and elevations, and were influenced by different variables (Fig. 4). Urochloa maxima was positively related to leaf litter depth and tree cover, and negatively to soil compaction, distance to highways and elevation. Melinis repens had a positive relation to stone cover. Eragrostis ciliaris 


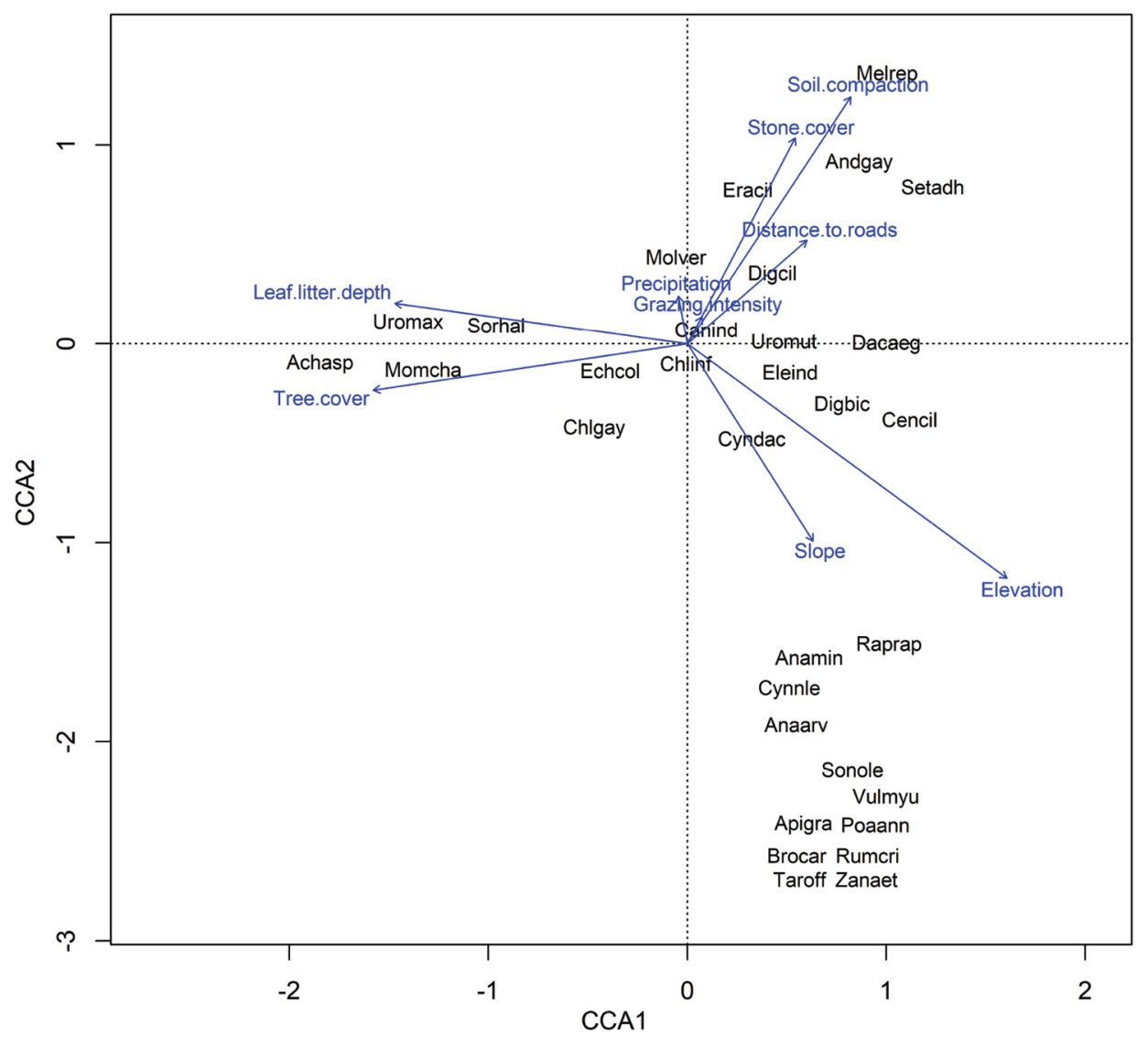

Fig. 3. Relationship of all alien species to environmental variables, as shown by a canonical correspondence analysis (CCA). The constrained inertia (= weighted variance) of 4.4619 and a significance of 0.001 in the CCA show that the species were related to different variables. The first axis had a relative constrained inertia of 0.8227 and the second 0.4060 . Species acronyms can be found in Table 1 .

was negatively related to tree cover and leaf depth but positively to elevation, soil compaction and distance to highways. Cynodon dactylon was negatively related to the second axis, representing grazing intensity and elevation.

\section{DISCUSSION}

Floristic composition and groups: Composition of the native ruderal flora was similar to that found in other studies in central Mexico, with Asteraceae, Poaceae and Fabaceae as the most species-rich families in ruderal vegetation (Flores-Huitzil et al., 2020; Vibrans, 1998; Villaseñor \& Espinosa-García, 2004). In our study, Poaceae accounted for $62.5 \%$ of all registered alien species. Even though this study concentrated on herbaceous species only, Poaceae had a remarkably large number of alien species. Villaseñor and Espinosa-García (2004) found that $27.7 \%$ of all alien species in Mexico belong to Poaceae, a tendency which was confirmed by Cuevas-Guzmán et al. (2004) for the Estación Científica Las Joyas (ECLJ) in the Biosphere Reserve Sierra de Manantlán where $26.3 \%$ of the alien species were grasses (Cuevas-Guzmán et al., 2004). Globally, only around $15 \%$ of alien species belong to the family Poaceae (Villaseñor \& Espinosa-García, 2004). Other authors also emphasize that most 


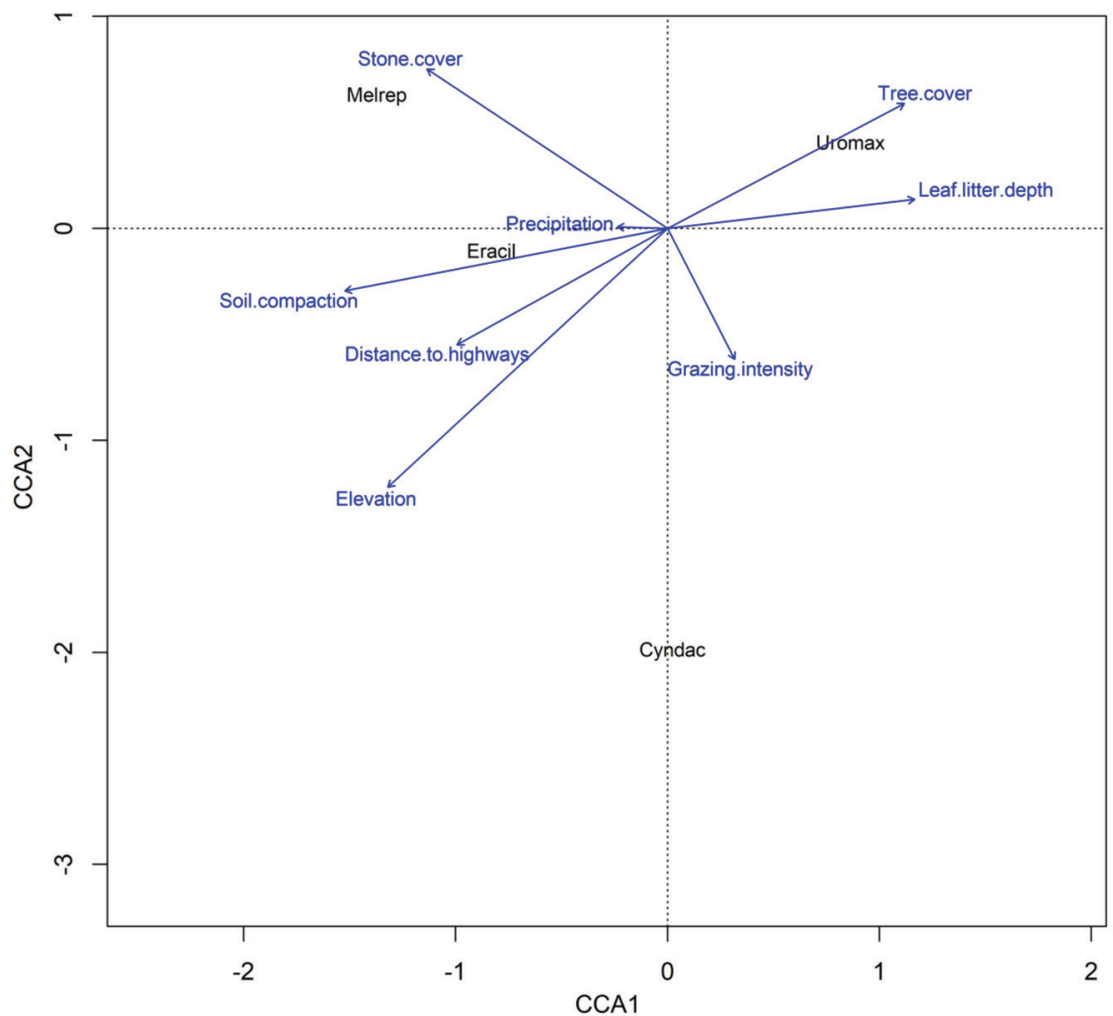

Fig. 4. Canonical correspondence analysis showing the relation of (invasive) alien species with the highest IVI to environmental variables, with a constrained inertia (= weighted variance) of 2.17 and a significance of 0.001 . The ANOVA showed a constrained inertia of 0.89 for the first axis and 0.66 for the second. Melrep $=$ Melinis repens, Eracil $=$ Eragrostis ciliaris, Uromax $=$ Urochloa maxima, Cyndac $=$ Cynodon dactylon .

of the invasive (as opposed to merely naturalised) alien weeds in Mexico were grasses (Espinosa-García et al., 2004; Vibrans, 2016). This may be due to the effects of forage grass introductions, as explained in the next paragraph. In contrast, Asteraceae, the most species rich family for native species, had only two alien species.

The cluster analysis showed elevationbased division between species found at higher elevations and species at low and middle elevations; there is some overlap around $1700 \mathrm{~m}$. This division reflects changes in the natural vegetation (from pine-oak to tropical forests) and is mainly due to the presence or absence of winter frosts. Most of the ruderal species of the temperate group originated in Europe and Asia, whereas the other group was dominated by African species, mainly grasses (EspinosaGarcía \& Villaseñor, 2017; Villaseñor \& Espinosa-García, 2004) introduced as forage plants for cattle ranching. Some escaped cultivation and turned into highly invasive species which are a threat to the natural vegetation, as in other parts of the Neotropics (Williams \& Baruch, 2000). Though there is no published evidence of African grass invasions in the study region, the authorities responsible for the protected areas in the region reported problems with invasive grasses that appeared only a few years ago and already cover large areas (P. RamosSuárez, pers. comm., 2018).

Environmental variables: Only a few species correlated clearly with environmental variables. Three sets of variables define 
different types of habitats: tree cover and leaf litter depth, stone cover and soil compaction, and elevation and slope. Sites with high tree cover and leaf litter depth can be considered less disturbed. Thus, species such as Achyranthes aspera and Urochloa maxima, which are related to those variables, could probably invade natural habitats more easily. Species positively related to stone cover and soil compaction might be more representative of recently disturbed sites, and surviving extreme conditions (Aziz \& Khan, 1993), thus they may have a lower risk of invasiveness. Taraxacum officinale, Rumex crispus, Sonchus oleraceus and others are associated with higher elevation and steeper slopes and can therefore be expected to survive lower temperatures and less sunlight. They are mainly European species adapted to temperate climates (Schmeil et al., 1959).

Potentially invasive species: As our study is a snapshot of the current situation, it is difficult to reliably identify invasive species. The definition of invasive species by Richardson et al. (2000) is based on the increase of spatial distribution over time and its impact. To be able to capture such a process, the species' distribution would have to be monitored for some time. Considering the small numbers of alien herbaceous species in the study area and the lack of correlation with different environmental variables, we suggest that most species are in an early stage of invasion (Aikio et al., 2010; Pérez-Postigo et al., 2021). However, species with a high IVI are possibly already causing significant changes to the ecosystems. The four species identified as potentially invasive not only have the highest IVIs in some transects but also a broad elevational range that excludes only the highest elevations (Fig. 2).

The species with the highest IVI, Urochloa maxima, commonly known as Guinea grass, was introduced to the Americas from Africa for cattle grazing and in some cases for erosion control (Moore, 2010; Overholt \& Franck, 2017; Ramirez-Yañez et al., 2007). This species is very tall, up to $3 \mathrm{~m}$ in height (Veldman et al., 2009), taller than most native herbaceous species. This can be an advantage in the competition for light and other resources. In Southern USA it has become invasive, displacing valuable native plants and forming extensive monospecific populations (Ramirez-Yañez et al., 2007). Guinea grass was also introduced into the Mediterranean and temperate regions where it became invasive (Clark et al., 2008; Verloove, 2014).

Urochloa maxima has been registered as one of the most important invasive species of African origin in other parts of Mexico (Rzedowski \& Calderon de Rzedowski, 1990; Vibrans, 2004). It is also known to be very abundant in tropical dry forests where it forms dominant stands (Romero Martins et al., 2007; Sampaio \& Schmidt, 2013; Veldman et al., 2009). It particularly invades forests disturbed by logging since, although the species can germinate below thick layers of leaf litter, it needs sufficient light to grow (Veldman \& Putz, 2010). Our results did not confirm this but rather showed a positive relationship between leaf litter depth and tree cover. Vegetation affected by fire is often dominated by Urochloa maxima (Lu \& DeLay, 2016; Veldman, 2010). The considerable biomass produced by this plant also provides large quantities of fuel which propagate fires (Veldman et al., 2009). Its robust and deep root systems and fastgrowing stalks allows it to recover rapidly after fires (Wied et al., 2020). These traits also make it very resistant to eradication efforts, such as mowing and herbicides (Ammondt et al., 2013; Clark et al., 2008).

Melinis repens, Natal grass, originated in Southern Africa and has an introduced range from Africa to Australia, Asia and America (Moore, 2010; Pyšek et al., 2020; Romero Martins et al., 2007). It was first recorded in the USA in the $19^{\text {th }}$ century (Stokes, 2010). In Mexico it was first found in 1945 after it escaped from experimental cultivation (Itié, 1945). It is one of the most invasive species globally, and in Mexico it is also causing damage, especially by modifying fire regimes (Espinosa-García \& Villaseñor, 2017; Gonçalves Rolim et al., 2014; Martínez-de la Cruz et al., 2015; Pyšek et al., 
2020; Rzedowski \& Calderon de Rzedowski, 1990; Space et al., 2000).

The species was initially introduced to Mexico as a potential forage grass but was not suitable for cattle grazing. The lack of grazing led to an increase in its populations (Gutiérrez Gutiérrez et al., 2019; Melgoza Castillo et al., 2014). It is widely distributed in the country, particularly in arid areas, in tropical dry forests and even in temperate regions of Mexico (Vibrans, 2004). Different chemical eradication methods have not been successful. The longevity of seeds on the surface is one month, whereas buried seeds can survive for over one year. Maximum germination was found at temperatures of $20-35^{\circ} \mathrm{C}$ (Melgoza Castillo et al., 2014; Stokes, 2010; Stokes et al., 2011) and its growth is enhanced by fire, thus threatening particularly fire sensitive species (Melgoza Castillo et al., 2014; Overholt \& Franck, 2017).

Melinis repens is more abundant, produces more biomass in ruderal vegetation and is more likely to invade roadsides than other habitats (David \& Menges, 2011). In our study, Melinis repens was clearly associated with soil compaction and stone cover - typical conditions in the immediate vicinity of roads. This coincides with qualitative observations in the region and with results in the Atlantic forest of Brazil (de Paula et al., 2015).

Another South African grass introduced to America as forage is Eragrostis ciliaris. It was the third most important species in our survey. This species can adapt to harsh conditions. It was found to invade extreme sites, such as desert areas and bare volcanic rocks after eruptions (Aziz \& Khan 1993; Rejmánek et al., 1982). Eragrostis ciliaris is known in Africa and Asia and is widely distributed in North and South America (Pyšek et al., 2020). The species is present but not highly invasive and does not cause damage to natural ecosystems in many of these regions (Gonçalves Rolim et al., 2014; Pyšek et al., 2020; Veldman, 2010). The species has been found in at least 20 of the 32 states in Mexico (Espinosa-García \& Villaseñor, 2017), but there are no detailed data on its effects. We can expect it to form part of the natural succession of new or disturbed sites and be replaced by other species during the succession process. Still, it could be competing with highly specialised species such as endemic lithophytes.

Bermuda grass, Cynodon dactylon, has been introduced in tropical and subtropical regions worldwide (Espinosa-García \& Villaseñor, 2017; Gonçalves Rolim et al., 2014; Mack, 2001; Moore, 2010; Romero Martins et al., 2007; Sampaio \& Schmidt, 2013; Sánchez Medrano, 2018; Space et al., 2000) and in the US since the $19^{\text {th }}$ century (Mack \& Lonsdale, 2001). For the Southern states of the USA, it is one of the alien species that causes the most concern (Espinosa-García \& Villaseñor, 2017; Gonçalves Rolim et al., 2014; Mack, 2001; Moore, 2010; Romero Martins et al., 2007; Sampaio \& Schmidt, 2013; Sánchez Medrano, 2018; Space et al., 2000). In some regions in Pakistan, Bermuda grass was the most dominant alien species (Javaid \& Riaz, 2012; Shabbir \& Bajwa, 2006). It is highly abundant in Northern and central Mexico, where it occasionally dominates the natural vegetation (Espinosa-García \& Villaseñor, 2017; Sánchez Medrano, 2018; Vibrans, 1998).

Cynodon dactylon, a C4 grass, is more effective than other native $\mathrm{C} 4$ grasses in its introduced range (Mojzes \& Kalapos, 2008). It is also tolerant to burning (Grace et al., 2001). A climatic niche model showed a potential distribution that included tropical, subtropical and temperate regions (Barney \& DiTomaso, 2011). Although Bermuda grass grows in temperate regions, its growth is restricted by very low temperatures (Alexander et al., 2011; Grace et al., 2001). Treatment with herbicides is not effective for eradication of Cynodon dactylon (Burkhart, 2004). It has been shown to alter soil properties and have a negative impact on avian and mammalian species (Barnes et al., 2013).

All four species were introduced as forage grass and escaped cultivation. They are known invaders in other regions where they have displaced the natural vegetation. Although in the study area the species still have quite low relative abundances and frequencies along 
roadsides, they are expected to spread into the natural vegetation in the near future. To prevent possible damage to the natural ecosystems, their advance along roadsides and into the natural vegetation should be prevented, along with generalised measures to minimise unnecessary disturbances and new introductions. We suggest that the four potentially invasive species should be the focus of detection, eradication and containment efforts in the more natural, conserved vegetation of the region. Since these species react to different environmental factors, management must be adapted to each species individually.

Conclusion: The most common and abundant alien species were grasses, all other families had only one or two species and limited abundance. The species formed three clusters - temperate, tropical and rare species - related to elevation and the geographic origin of the species.

Consequently, the most invasive species of the region were grasses, all of them African, introduced intentionally for ranching. Whereas Urochloa maxima, Cynodon dactylon and Melinis repens are known invaders elsewhere, the impacts of Eragrostis ciliaris are not yet well-known and should be explored further.

Ethical statement: authors declare that they all agree with this publication and made significant contributions; that there is no conflict of interest of any kind; and that we followed all pertinent ethical and legal procedures and requirements. All financial sources are fully and clearly stated in the acknowledgements section. A signed document has been filed in the journal archives.

\section{ACKNOWLEDGMENTS}

This study was conducted in the context of the Doctoral Program in Sciences in Biosystematics, Ecology, and Management of Natural and Agricultural Resources (BEMARENA) of the Universidad de Guadalajara, Mexico. The Consejo Nacional de Ciencia y Tecnología
(CONACyT) funded the research through a doctoral thesis grant to the first author. We received financial support from the University of Guadalajara through the program Fortalecimiento a la investigación. Members of the Laboratory of Botany at the Centro Universitario de la Costa Sur helped with the field work and species identification. The authors declare no conflicts of interest.

\section{RESUMEN}

\section{Composición florística y potencial de invasión de plantas herbáceas exóticas en el occidente de México}

Introducción: El número de especies de plantas exóticas está aumentando en todo el mundo, pero no todas las especies se convierten en invasoras. Si bien para algunas regiones la introducción de especies se ha documentado durante varias décadas, para el occidente de México los conocimientos sobre especies exóticas son escasos. Aquí, estudiamos la vegetación de los bordes de las carreteras a lo largo de un gradiente altitudinal en una región que incluye un área protegida.

Objetivos: Estudiamos la composición florística de las herbáceas exóticas, sus patrones de distribución y su relación con diversos factores ambientales. El índice de valor de importancia (IVI) de las especies identificó las especies más importantes, y por lo tanto probablemente invasoras.

Métodos: Durante el 2017 y 2018 se documentó la vegetación del borde de la carretera con 4-6 transectos en cada nivel de elevación de $300 \mathrm{~m}$, de 0 a $2100 \mathrm{~m}$, para un total de 37. Cada transecto constó de cinco parcelas de $1 \mathrm{~m}^{2}$. Se registraron todas las especies herbáceas y se identificaron las especies introducidas. Un análisis de agrupamiento identificó los grupos de especies basado en sus patrones de distribución relacionadas con la elevación. Las especies potencialmente invasoras se identificaron por su IVI, basado en la suma de la frecuencia relativa y la densidad relativa. La influencia de las variables ambientales fue estudiada mediante un análisis de correspondencia canónica.

Resultados: La mayoría de las especies exóticas fueron pastos, otras familias estuvieron representadas por una o dos especies. Las especies formaron tres grupos principales. El primero incluyó especies raras; el segundo las especies distribuidas principalmente en elevaciones altas, y el tercero incluyó los taxones con una distribución desde el nivel del mar hasta elevaciones medias. Las especies más importantes y potencialmente invasoras fueron: Urochloa maxima, Melinis repens, Eragrostis ciliaris y Cynodon dactylon, todas gramíneas africanas introducidas como forraje para el ganado. El IVI de las especies se relacionó con la cobertura de árboles, profundidad de hojarasca y con pedregosidad para algunas especies, y para otras con la 
compactación del suelo, la distancia a carreteras (federales) y elevación.

Conclusiones: Las especies ruderales exóticas se agruparon según el clima general (templado vs. tropical). Las gramíneas de origen africano son las que más preocupan como especies invasoras. Aunque la mayoría de las introducciones están relacionadas con las alteraciones humanas, cada especie se vuelve dominante en determinadas condiciones ambientales. Por ello, los programas de manejo deben ajustarse específicamente a cada especie exótica invasora.

Palabras clave: variables ambientales; plantas exóticas; hierbas invasoras; malezas ruderales; Sierra de Manantlán.

\section{REFERENCES}

Aikio, S., Duncan, R. P., \& Hulme, P. E. (2010). Lagphases in alien plant invasions: separating the facts from the artefacts. Oikos, 119(2), 370-378. https:// doi.org/10.1111/j.1600-0706.2009.17963.x

Alexander, J. M., Kueffer, C., Daehler, C. C., Edwards, P. J., Pauchard, A., Seipel, T., \& MIREN Consortium. (2011). Assembly of nonnative floras along elevational gradients explained by directional ecological filtering. PNAS, 108(2), 656-661. https://doi. org/10.1073/pnas. 1013136108

Ammondt, S. A., Litton, C. M., Ellsworth, L. M., \& Leary, J. K. (2013). Restoration of native plant communities in a Hawaiian dry lowland ecosystem dominated by the invasive grass Megathyrsus maximus. Applied Vegetation Science, 16(1), 29-39. https://doi. org/10.1111/j.1654-109X.2012.01208.x

Aziz, S., \& Khan, M. A. (1993). Survivorship patterns of some desert plants. Pakistan Journal of Botany, $25(1), 67-72$.

Barnes, T. G., DeMaso, S. J., \& Bahm, M. A. (2013). The impact of 3 exotic, invasive grasses in the southeastern United States on wildlife. Wildlife Society Bulletin, 37(3), 497-502. https://doi.org/10.1002/wsb.316

Barney, J. N., \& DiTomaso, J. M. (2011). Global climate niche estimates for bioenergy crops and invasive species of agronomic origin: potential problems and opportunities. PLOS ONE, 6(3), 1-11. https://doi. org/10.1371/journal.pone.0017222

Barney, J. N., \& Whitlow, T. H. (2008). A unifying framework for biological invasions: The state factor model. Biological Invasions, 10(3), 259-272. https:// doi.org/10.1007/s10530-0079127-8

Bastida, F., Zsolnay, A., Hernández, T., \& García, C. (2008). Past, present and future of soil quality indices: a biological perspective. Geoderma, 147(3-4), 159-171. https://doi.org/10.1016/j.geoderma.2008.08.007
Borcard, D., Legendre P., \& Drapeau, P. (1992). Partialling out the spatial component of ecological variation. Ecology, 73(3), 1045-1055.

Burkhart, J. K. (2004). Vegetation response in field margins managed for northern bobwhite (Colinus virginianus) and potential negative impacts of bermudagrass (Cynodon dactylon) (Master's thesis). University of Georgia, USA.

Catford, J. A., Jansson, R., \& Nilsson, C. (2009). Reducing redundancy in invasion ecology by integrating hypotheses into a single theoretical framework. Diversity and Distributions, 15(1), 22-40. https://doi. org/10.1111/j.1472-4642.2008.00521.x

Catford, J. A., Vesk, P. A., Richardson, D. M., \& Pyšek, P. (2012). Quantifying levels of biological invasion: towards the objective classification of invaded and invasible ecosystems. Global Change Biology, 18(1), 44-62. https://doi. org/10.1111/j.1365-2486.2011.02549.x

Chapin, F. S., Bloom, A. J., Field, C. B., \& Waring, R. H. (1987). Plant responses to multiple environmental factors. BioScience, 37(1), 49-57.

Clark, D. W., Hillis-Starr, Z., \& Furqueron, C. (2008). "Rats and weeds and lizards - Oh my!" Eradication of Rattus rattus and control of invasive exotic plants on Buck Island, U. S. Virgin Islands. U.S. National Park Service Publications and Papers, 19, 106-111.

Clarke, K. R., Gorley, R. N., Somerfield, P. J., \& Warwick, R. M. (2014). Change in marine communities: an approach to statistical analysis and interpretation (3 ${ }^{\text {rd }}$ Ed.) PRIMER-E.

Cruz Angón, A., Ordorica Hermosillo, A., Valero Padilla, J., \& Melgarejo, J. (2017). La biodiversidad en Jalisco. Estudio de Estado. Comisión Nacional para el Conocimiento y Uso de la Biodiversidad, Secretaría de Medio Ambiente y Desarrollo Territorial, Ciudad de México.

Cuevas-Guzmán, R., Koch, S., García-Moya, E., NúñezLópez, N. M., \& Jardel-Peláez, E. J. (2004). Flora vascular de la Estación Científica las Joyas. In R. Cuevas Guzmán \& E. J. Jardel (Eds.), Flora y vegetación de la Estación Científica Las Joyas (pp. 119-176). Universidad de Guadalajara, México.

Curtis, J. T., \& McIntosh, R. P. (1950). The interrelations of certain analytic and synthetic phytosociological characters. Ecology, 31(3), 434-455.

Curtis, J. T., \& McIntosh, R. P. (1951). An upland forest continuum in the prairie-forest border region of Wisconsin. Ecology, 32(3), 476-496. https://doi. org/10.2307/1931725

David, A. S., \& Menges, E. S. (2011). Microhabitat preference constrains invasive spread of non-native 
natal grass. Biological Invasions, 13(10), 2309-2322. https://doi.org/10.1007/s10530-011-0044-5

Dawson, W., Burslem, D. F. R. P., \& Hulme, P. E. (2009). Factors explaining alien plant invasion success in a tropical ecosystem differ at each stage of invasion. Journal of Ecology, 97(4), 657-665. https://doi. org/10.1111/j.1365-2745.2009.01519.x

de Paula, L. F. A., Negreiros, D., Azevedo, L. O., Fernandes, R. L., Stehmann, J. R., \& Silveira, F. A. O. (2015). Functional ecology as a missing link for conservation of a resource-limited flora in the Atlantic forest. Biodiversity \& Conservation, 24(9), 22392253. https://doi.org/10.1007/s10531-015-0904-x

Ellis, E. C., Goldewijk, K. K., Siebert, S., Lightman, D., \& Ramankutty, N. (2010). Anthropogenic transformation of the biomes, 1700 to 2000. Global Ecology and Biogeography, 19(5), 589-606. https://doi. org/10.1111/j.1466-8238.2010.00540.x

Elton, C. S. (1958). The ecology of invasions by animals and plants. Butler and Tanner.

Espinosa-García, F. J., \& Villaseñor, J. L. (2017). Biodiversity, distribution, ecology and management of non-native weeds in Mexico: a review. Revista Mexicana de Biodiversidad, 88, 76-96. https://doi. org/10.1016/j.rmb.2017.10.010

Espinosa-García, F. J., Villaseñor, J. L., \& Vibrans, H. (2004). The rich generally get richer, but there are exceptions: Correlations between species richness of native plant species and alien weeds in Mexico. Diversity and Distributions, 10(5-6), 399-407. https://doi.org/10.1111/j.1366-9516.2004.00099.x

Flores-Huitzil, E. C., Coombes, A. J., \& Villaseñor, J. L. (2020). Las angiospermas ruderales del municipio Coronango, Puebla, México. Acta Botánica Mexicana, 127, 1-19. https://doi.org/10.21829/ abm127.2020.1601

Gobierno de México. (25 de junio, 2018). Atlas de Caminos y Carreteras del Estado de Jalisco Gobierno de México [Base de datos]. https://datos.gob.mx

Gonçalves Rolim, R., Abreu de Ferreira, P. M., Schneider, A. A., \& Overbeck, G. E. (2014). How much do we know about distribution and ecology of naturalized and invasive alien plant species? A case study from subtropical southern Brazil. Biological Invasions, 17(5), 1-23. https://doi.org/10.1007/ s10530-014-0811-1

Grace, J. B., Smith, M. D., Grace, S. L., Collins, S. L., \& Stohlgren, T. J. (2001). Interactions between fire and invasive plants in temperate grasslands of North. In K. E. M. Galley, \& T. P. Wilson (Eds.), Proceedings of the invasive species workshop: the role of fire in the control and spread of invasive species (No. 11, pp. 40-65). Fire Conference 2000: the First National Congress on Fire Ecology, Prevention, and
Management. Miscellaneous Publication No. 11, Tall Timbers Research Station, Tallahassee, USA.

Gutiérrez Gutiérrez, G. O., Morales Nieto, C. R., Villalobos González, J. C., Ruíz Barrera, O., Ortega Gutiérrez, J. Á., \& Palacio Nuñez, J. (2019). Botanical composition and nutritive value of the diet consumed by cattle in an area invaded by natal grass [Melinis repens (Willd.) Zizka]. Revista Mexicana de Ciencias Pecuarias, 10(1), 212-226. https://doi.org/10.22319/ rmcp.v10i1.4451

Hierro, J. L., Maron, J. L., \& Callaway, R. M. (2005). A biogeographical approach to plant invasions: The importance of studying exotics in their introduced and native range. Journal of Ecology, 93(1), 5-15. https://doi.org/10.1111/j.1365-2745.2004.00953.x

Hijmans, R. J., Cameron, S. E., Parra, J. L., Jones, P. G., \& Jarvis, A. (2005). Very high resolution interpolated climate surfaces for global land areas. International Journal of Climatology, 25(15), 1965-1978. https:// doi.org/10.1002/joc. 1276

INE (Instituto Nacional de Ecología). (2000). Programa de Manejo Reserva de la Biosfera Sierra de Manantlán, México. Secretaría de Medio Ambiente y Recursos Naturales - Instituto Nacional de Ecología, México.

Itié, G. (1945). Un zacate emigrante (Tricholaena rosea Nees). Boletín de la Sociedad Botánica de México, 2, 19-20. https://doi.org/10.17129/botsci.920

Jarić, I., \& Cvijanovic, G. (2012). The tens rule in invasion biology: Measure of a true impact or our lack of knowledge and understanding? Environmental Management, 50(6), 979-981. https://doi.org/10.1007/ s00267-012-9951-1

Javaid, A., \& Riaz, T. (2012). Parthenium hysterophorus L., an alien invasive weed threatening natural vegetation in Punjab, Pakistan. Pakistan Journal of Biological Sciences, 44, 123-126.

Jeschke, J. M., Gómez Aparicio, L., Haider, S., Heger, T., Lortie, C. J., Pyšek, P., \& Strayer, D. L. (2012). Support for major hypotheses in invasion biology is uneven and declining. NeoBiota, 14, 1-20. https:// doi.org/10.3897/neobiota.14.3435

Kelly, I. T. (1945). The archaeology of the Autlan-Tuxcacuesco area of Jalisco. University of California Press.

Kuhn, M. (2020). caret: Classification and Regression Training. (Version 6.0-86, R package) https://CRAN.Rproject.org/package $=$ caret

Lu, P. L., \& DeLay, J. K. (2016). Vegetation and fire in lowland dry forest at Wa'ahila Ridge on O'ahu, Hawai'i. PhytoKeys, 68(1), 51-64. https://doi. org/10.3897/phytokeys.68.7130 
Mack, R. N. (1991). The commercial seed trade: an early disperser of weeds in the United States. Economic Botany, 45(2), 257-273.

Mack, R. N. (2001). Motivations and consequences of the human dispersal of plants. In J. A. McNeely (Ed.), The great reshuffling. Human dimensions of invasive alien species (pp. 23-34). International Union for Conservation of Nature and Natural Resources.

Mack, R. N., Simberloff, D., Lonsdale, W. M., Evans, H., Clout, M., \& Bazzaz, F. A. (2000). Biotic invasions: causes, epidemiology, global consequences, and control. Ecological Applications, 10(3), 689-710.

Mack, R. N., \& Lonsdale, W. M. (2001). Humans as global plant dispersers: Getting more than we bargained for. BioScience, 51(2), 95-102. https://doi. org/10.1641/0006-3568(2001)051[0095:HAGPDG]2 $0 . \mathrm{CO} ; 2$

Mandal, U. K., Rao, K. V., Mishra, P. K., Vittal, K. P. R., Sharma, K. L., Narsimlu, B., \& Venkanna, K. (2005). Soil infiltration, runoff and sediment yield from a shallow soil with varied stone cover and intensity of rain. European Journal of Soil Science, 56(4), $435-443$.

Martínez-de la Cruz, I., Vibrans, H., Lozada-Pérez, L., Romero-Manzanares, A., Aguilera-Gómez, L. I., \& Rivas-Manzano, I. V. (2015). Plantas ruderales del área urbana de Malinalco, Estado de México, México. Botanical Sciences, 93(4), 907-919. https://doi. org/10.17129/botsci.213

Melgoza Castillo, A., Balandrán Valladares, I. M., MataGonzález, R., \& Pinedo Álvarez, C. (2014). Biología del pasto rosado Melinis repens (Willd.) e implicaciones para su aprovechamiento o control. Revisión. Revista Mexicana de Ciencias Pecuarias, 5(4), 429-442.

Mojzes, A., \& Kalapos, T. (2008). Leaf gas exchange responses to abrupt changes in light intensity for two invasive and two non-invasive $\mathrm{C}_{4}$ grass species. Environmental and Experimental Botany, 64(3), 232-238. https://doi.org/10.1016/j.envexpbot.2008.06.003

Moore, S. F. (2010). Effects of guineagrass on northern bobwhite habitat use (Master's thesis). Texas A\&M University-Kingsville, USA. https://doi.org/10.1017/ CBO9781107415324.004

Neal, J. H. (1938). The effect of the degree of slope and rainfall characteristics on runoff and soil erosion. Research Bulletin, 280, 525-532. https://doi. org/10.2136/sssaj1938.036159950002000c0083x

Oksanen, J., Blanchet, F. G., Friendly, M., Kindt, R., Legendre, P., McGlinn, D., Minchin, P. R., O'Hara, R. B., Simpson, G. L., Solymos, P., Stevens, M. H. H., Szoecs, E., \& Wagner, H. (2019). vegan: Community Ecology Package (Version 2.5-6, R package). https://CRAN.R-project.org/package= $=$ vegan
Overholt, W. A., \& Franck, A. R. (2017). The invasive legacy of forage grass introductions into Florida. Natural Areas Journal, 37(2), 254-264. https://doi. org/10.3375/043.037.0214

Passioura, J. B. (1991). Soil structure and plant-growth. Australian Journal of Soil Research, 29(6), 717-728.

Pauchard, A., \& Alaback, P. B. (2004). Influence of elevation, land use, and landscape context of patterns of alien plant invasions along roadsides in protected areas of south-central Chile. Conservation Biology, 18(1), 238-248.

Pauchard, A., Kueffer, C., Dietz, H., Daehler, C. C., Alexander, J., Edwards, P. J., Arévalo, J. R., Cavieres, L. A., Guisan, A., Haider, S., Jakobs, G., McDougall, K., Millar, C. I., Naylor, B. J., Parks, C. G., Rew, L. J., \& Seipel, T. (2009). Ain't no mountain high enough: plant invasions reaching new elevations. Frontiers in Ecology and the Environment, 7(9), 479-486. https://doi.org/10.1890/080072

Pejchar, L., \& Mooney, H. A. (2009). Invasive species, ecosystem services and human well-being. Trends in Ecology \& Evolution, 24(9), 497-504. https://doi. org/10.1016/j.tree.2009.03.016

Pérez-Postigo, I., Bendix, J., Vibrans, H., \& CuevasGuzmán, R. (2021). Diversity of alien roadside herbs along an elevational gradient in Western Mexico. NeoBiota, 65, 71-91. https://doi.org/10.3897/ neobiota.65.67192

Pyšek, P., Pergl, J., van Kleunen, M., Dawson, W., Essl, F., Kreft, H., Weigelt, P., Wilson, J. R., Winter, M., \& Richardson, D. M. (2020). South Africa as a donor of naturalised and invasive plants to other parts of the world. In B. W. Van Wilgen, J. Measey, D. M. Richardson, J. R. Wilson, T. A. Zengeyads (Eds.), Biological Invasions in South Africa (pp. 759-786). Springer Nature Switzerland. https://doi. org/10.1007/978-3-030-32394-3 26

QGIS.org (2019). QGIS Geographic Information System, version 3.6.2. QGIS Association. http://www.qgis.org

R Core Team (2020). R: A language and environment for statistical computing. R Foundation for Statistical Computing, Vienna, Austria. https://www.R-project. org

Ramirez-Yañez, L. E., Ortega-S, J. A., Brennan, L. A., \& Rasmussen, G. A. (2007). Use of prescribed fire and cattle grazing to control guineagrass. In R. E. Master, \& K. E. M. Galley (Eds.), 23rd Tall Timbers Fire Ecology Conference: Fire in Grassland and Shrubland Ecosystems (pp. 240-245). Tall Timber Research Station.

Rejmánek, M., Haagerova, R., \& Haager, J. (1982). Progress of plant succession on the Paricutin Volcano: 25 years after activity ceased. American Midland Naturalist, 108(1), 194-198. 
Rejmánek, M., Richardson, D. M., Pyšek, P. (2005). Plant invasions and invasibility of plant communities. In E. van der Maarel (Ed.), Vegetation Ecology (pp. 332-355). Blackwell.

Richardson, D. M., Pyšek, P., Rejmánek, M., Barbour, M. G., Panetta, F. D., \& West, C. J. (2000). Naturalization and invasion of alien plant: concepts and definitions. Diversity and Distributions, 6(2), 93-107.

Romero Martins, C., Du Vall Hay, J., Valls, J. F. M., Leite, L. L., \& Barros Henriques, R. P. (2007). Study on alien gramineous of the Brasilia National Park, Federal District, Brazil. Natureza \& Conservação, 5(2), 93-100.

Rzedowski, J. (1978). Vegetación de México. Limusa.

Rzedowski, J., \& Calderon de Rzedowski, G. (1990). Nota sobre el elemento africano en la flora adventicia de México. Acta Botánica Mexicana, 12, 21-24.

Rzedowski, J., \& McVaugh, R. (1966). La vegetación de Nueva Galicia. University of Michigan Herbarium, USA.

Sampaio, A. B., \& Schmidt, I. B. (2013). Espécies exóticas invasoras em unidades de conservação federais do Brasil. Biodiversidade Brasileira, 3(2), 32-49.

Sánchez Medrano, F. Z. (2018). Distribución de especies de plantas nativas y exóticas al lado de caminos a lo largo de un gradiente altitudinal en el noreste de México (Master's thesis). Universidad Autónoma de Nuevo León, México.

Schmeil, O., Fitschen, J., \& Rauh, W. (1959). Flora von Deutschland. Quelle \& Meyer.

Shabbir, A., \& Bajwa, R. (2006). Distribution of parthenium weed (Parthenium hysterophorus L.), an alien invasive weed species threatening the biodiversity of Islamabad. Weed Biology and Management, 6(2), 89-95. https://doi.org/10.1111/j.1445-6664.2006.00202.x

Simberloff, D. (2011). Correspondence: Non-natives: 141 scientists object. Nature, 475, 36.

Sol, D. (2007). Do successful invaders exist? Pre-adaptations to novel environments in terrestrial vertebrates. In W. Nentwig (Ed.), Biological Invasions (pp. 127-143). Springer.

Space, J. C., Waterhouse, B., Denslow, J. S., \& Nelson, D. (2000). Invasive plant species on Rota, Commonwealth of the Northern Mariana Islands. U.S.D.A. Forest Service, Pacific Southwest Research Station Institute of Pacific Islands Forestry, Honolulu, USA.
Stokes, C. A. (2010). Biology, ecology and management of natalgrass (Melinis repens) (Master's thesis). University of Florida, USA.

Stokes, C. A., McDonald, G. E., Adams, C. R., Langeland, K. A., \& Miller, D. L. (2011). Seed biology and ecology of Natal grass (Melinis repens). Weed Science, 59(4), 527-532. https://doi.org/10.1614/ WS-D-11-00028.1

van Kleunen, M., Dawson, W., Essl, F., Pergl, J., Winter, M., Weber, E., Kreft, H., Weigelt, P., Kartesz, J., Nishino, M., Antonova, L. A., Barcelona, J. F., Cabezas, F. J., Cárdenas, D., Cárdenas-Toro, J., Castaño, N., Chacón, E., Chatelain, C., Ebel, A. L., ... Pyšek, P. (2015a). Global exchange and accumulation of nonnative plants. Nature, 525(7567), 100-103. https:// doi.org/10.1038/nature14910

van Kleunen, M., Dawson, W., \& Maurel, N. (2015b). Characteristics of successful alien plants. Molecular Ecology, 24(9), 1954-1968. https://doi.org/10.1111/ mec. 13013

Vázquez García, J. A., Cuevas Guzmán, R., Cochrane, T. S., Iltis, H. H., Santana, M. F. J., \& Guzmán, H. L. (1995). Flora de Manantlán. Botanical Research Institute of Texas.

Veldman, J. W. (2010). The nature of savannas that replace dry forests in Chiquitania, Bolivia (Doctoral thesis). University of Florida, USA.

Veldman, J. W., Mostacedo, B., Peña-Claros, M., \& Putz, F. E. (2009). Selective logging and fire as drivers of alien grass invasion in a Bolivian tropical dry forest. Forest Ecology and Management, 258(7), 16431649. https://doi.org/10.1016/j.foreco.2009.07.024

Veldman, J. W., \& Putz, F. E. (2010). Long-distance dispersal of invasive grasses by logging vehicles in a tropical dry forest. Biotropica, 42(6), 697-703. https://doi. org/10.1111/j.1744-7429.2010.00647.x

Verloove, F. (2014). Exotic grasses running wild: Megathyrsus maximus var. publiglumis (Poaceae, Paniceae) new to Spain. Bouteloua, 1(1), 55-60.

Vibrans, H. (1998). Native maize field weed communities in south-central Mexico. Weed Research, 38(2), 153-166. https://doi.org/10.1046/j.1365-3180.1998.00082.x

Vibrans, H. (2004). Taller sobre plantas invasivas en áreas naturales. XVI Congreso Mexicano de Botánica, Oaxaca, México.

Vibrans, H. (2016). Ethnobotany of Mexican weeds. In R. Lira (Ed.), Ethnobotany of Mexico, Ethnobiology (pp. 287-317). Springer. 
Villaseñor, J. L., \& Espinosa-García, F. J. (2004) The alien flowering plants of Mexico. Diversity and Distributions, 10(2), 113-123. https://doi. org/10.1111/j.1366-9516.2004.00059.x

Wied, J. P., Perotto-Baldivieso, H., Conkey, A. A. T., Brennan, L. A., \& Mata, J. M. (2020). Invasive grasses in South Texas rangelands: historical perspectives and future directions. Invasive Plant Science and Management, 13(2), 41-58. https://doi.org/10.1017/ inp. 2020.11

Williams, D. G., \& Baruch, Z. (2000). African grass invasion in the Americas: ecosystem consequences and the role of ecophysiology. Biological Invasions, 2(2), 123-140. https://doi.org/10.1023/A:1010040524588
Williamson, M. H., \& Fitter, A. (1996a). The varying success of invaders. Ecology, 77(6), 163-170.

Williamson, M. H., \& Fitter, A. (1996b). The characters of successful invaders. Biological Conservation, 78(6), 163-170. https://doi org/10.1016/0006-3207(96)00025-0

Woodward, C. L. (1996). Soil compaction and topsoil removal effects on soil properties and seedling growth in Amazonian Ecuador. Forest Ecology and Management, 82(1-3), 197-209. https:// doi.org/10.1016/0378-1127(95)03667-9 